\title{
Assessment on the Perception of Invasive Alien Spices (IAS) of Farmers and Stake Holders on the Agricultural Sector in Eastern Ethiopia
}

\author{
Yeneayehu Fenetahun Mihertu \\ Ethiopian Biodiversity Institute (EBI) Harar Biodiversity Center, Harar, Ethiopia
}

Email address:

yeneayehu07@gmail.com

To cite this article:

Yeneayehu Fenetahun Mihertu. Assessment on the Perception of Invasive Alien Spices (IAS) of Farmers and Stake Holders on the Agricultural Sector in Eastern Ethiopia. American Journal of Bioscience and Bioengineering. Vol. 5, No. 1, 2017, pp. 34-40.

doi: 10.11648/j.bio.20170501.16

Received: January 6, 2017; Accepted: January 18, 2017; Published: February 22, 2017

\begin{abstract}
Invasive species can be seen as species that are introduced in a new region, and that spreads rapidly. Invasive alien species (IAS) are characterized by rapid growth rates, extensive dispersal capabilities, large and rapid reproductive output and broad environmental tolerance. this assessment paper discuss on the general perception of IAS from three basic target groups (local farmers, both zonal, regional and woreda agricultural, environmental and forest experts). The assessment was based on three basic concepts that is (1). to understand the attitudes of the target group (evolution of the level of knowledge, awareness and need for information monitoring with related to invasive alien spices); (2). identifying the communication tools most frequently used; and (3). identify which best practices were implemented in order to control IAS with in the residence area. From the assessment data we can understand all target group were concerning on the issue of IAS even they have different level of knowledge and control mechanism and finally the target groups forwarded the following basic recommendation like further support and cooperation with regard to its fast and aggressive expansion of IAS and I also support and elaborate their recommendation.
\end{abstract}

Keywords: Agricultural Biodiversity, IAS, Impact, Target Group, Perception

\section{Introduction}

Invasive species can be seen as species that are introduced in a new region, and that spreads rapidly [14]. Or an alien species is an organism introduced outside its natural past or present distribution range by human agency, either directly or indirectly [2]. The deliberate or accidental introduction of non-indigenous species to new habitats has become an increasingly important aspect of global environmental change $[1,10,11,13]$ and can cause important economic, environmental and social losses [4]. Invasive alien species (IAS) are characterized by rapid growth rates, extensive dispersal capabilities, large and rapid reproductive output and broad environmental tolerance [3]. It is estimated that as many as $50 \%$ of invasive species in general can be classified as ecologically harmful, based on their actual impacts [15]. Once an invasive species becomes firmly established, its control often becomes difficult and eradication is usually impossible [13]. Therefore, exotic species will forever be common components of every ecosystem on Earth.

Currently, IAS, which is the second, next to habitat distraction to biodiversity threat [8]. Therefore, countries should evaluate the ecological distribution and socioeconomic impact of these species to take appropriate management and control measures. In Ethiopia, there are about 32 IAS and from these 24 identified and 8 of them are still unidentified [12]. Among these invasive alien species Mesquites (Prosopis juliflora), parthenium weed (Parthenium hysterophorus), water hyacinth (Eichhornia crassipes), Lantana camara, and Acacia species are causing major problems in the country. Currently, it is observed that the IAS species has been increasing in density as well as area coverage from year to year even from month to month and heavily infests most agricultural as well as potential range lands in the eastern part of Ethiopia. The impacts of alien species are enormous. They cause alteration in ecosystem processes and community 
structure, decline in abundance and richness of native flora [5, $16,17]$. Since eastern part of Ethiopia is one of the country's hotspots for farmers indigenous Crop, animal and plant diversity but now a day this biological diversity is highly eroded and disappeared due to the occurrence and rapid invasion of invasive alien spice in the area.

Communication is part of preventive actions on invasive alien species (IAS) which are recognized as much more effective than control actions because of a higher cost/benefit ratio from both an ecological and economical perspective [18]. But the success of communication lies in its aptitude in delivering a message and in changing behaviors. Determining the effectiveness of an awareness campaign through an appropriate monitoring is therefore a key component of every communication strategies. Surprisingly, such assessments are poorly documented in the literature dedicated to communication programs. Although it is logical and strongly recommended, in practice it is often forgotten [9] or underestimated. Results from such evaluation help in defining the communication actions which work or do not work, which communication channels or tools are most suitable. It also helps in determining if the message is received by the target audience and how it is perceived.
Therefore, this assessment was aims to address the following basic objectives (1). To understand the attitudes of the target group (evolution of the level of knowledge, awareness and need for information monitoring with related to invasive alien spices; (2). identifying the communication tools most frequently used; (3). To know the perception of the target population (farmers and stake holders) towards IAS and (4). identify which best practices were implemented in order to control IAS with in the residence area.

\section{Materials and Methods}

\subsection{Sampling Design}

This assessment was addressed to farmers, agricultural, environmental and forest professionals from two zonal administration (East Hararghe zone and West Hararghe zone), Harari Regional State and Dire Dawa city administration in eastern Ethiopia. Three target groups were considered in this study: (1) local farmers; (2) zonal, regional and woreda agricultural experts; (3) Zonal, regional and woreda environment and forest experts (table 1).

Table 1. Target group.

\begin{tabular}{lll}
\hline No. & Target group & Description \\
\hline 1. & Local farmers & Producers, consumers and sellers in agricultural crops \\
2. & Both zonal, regional and woreda agricultural experts & Civil servant in charge of agricultural areas working in municipalities \\
3. & Both zonal, regional and woreda environmental and forest experts & Civil servant in charge of environmental and forest working in municipalities \\
\hline
\end{tabular}

The assessment data were collected from local farmers and stake holders or experts through semi-structure questionnaire, face to face interview and focus group discussion based methods given by [7]. A total of 552 assessment data were collected from 552 interviewers (416 male and 136 female). From the total interviewers 480 (360 male and 120 female) were local farmers selected from 16 woreda (4 woreda from East haraghe, 4 woreda from West haraghe, 4 woreda from Harari regional state and 4 woreda from Dire Dawa city administration) and from each woreda a total of 30 local farmers were selected randomly based on their area and abundance on IAS around the area. And the reaming 72 (56 male and 16 female) 8 from the two zone (East and West hararghe zone), Harari regional State and Dire Dawa
City administration from each 1 agricultural expert and 1 environment and forest expert and total of two from each and the rest 64 interviewers were from woreda experts and from each woreda 4 interviewer were selected purposefully based on their professional area of experts. The assessment was conducted from Aug, 2016 to Nov, 2016 at respondent's house and fields.

\subsection{Data Analysis}

All data were analyzed in Access and Excel databases. Examples of questions are indicated in table 2. Basic statistics (\# and \%) were computed for each question [18].

Table 2. Examples of questions included during the assessment.

\begin{tabular}{|c|c|}
\hline Section & Question \\
\hline \multirow{6}{*}{ 1. Knowledge, understanding and concern } & Do you know what is an invasive plant (or invasive alien plant)? \\
\hline & If yes, what do you know? \\
\hline & Do you know examples of invasive plants? \\
\hline & According to you, what are the impacts of invasive plants? \\
\hline & Do you think it is an important issue? \\
\hline & Do you feel concerned by this issue? \\
\hline 2. Information and communication & Do you feel enough and already informed about invasive plants? \\
\hline \multirow{4}{*}{ 3. Best control practices of IAS were implemented } & Do you have any control practice? \\
\hline & If yes, what are those? \\
\hline & Do you have any support based on the control method? \\
\hline & What will be you recommendation based on controlling IAS? \\
\hline
\end{tabular}

Answers were compared with the definition of invasive species proposed in the Convention on Biological Diversity (2002) 
referred by [18], “An invasive alien species is a species, sub-species or variety introduced by men outside its natural distribution area, able to survive, reproduce and spread in a new environment, which may cause environmental, economic, socio-cultural and/or public health impacts when established". This definition highlights five main notions to refer concerning invasive plants: (1) spatial origin; (2) introduction by men; (3) naturalization; (4) expansion, spread and (5) impacts. The target group level of knowledge was evaluated following the criteria presented in table 3.

Table 3. Target group level of knowledge.

\begin{tabular}{ll}
\hline Level of knowledge & Criteria \\
\hline High & $\begin{array}{l}\text { Those who answered "Yes" to the question "Do you know what an invasive plant is?" and indicated at least three notions of } \\
\text { the definition and at least two correct examples and at least one impact. } \\
\text { Those who answered "Yes" to the question "Do you know what an invasive plant is?" and indicated at least one notion of the } \\
\text { definition and/or at least one correct example. } \\
\text { Those who answered "No" to the question "Do you know what an invasive plant is?" or those who answered "Yes" but } \\
\text { indicated no notions and no examples and no impacts or those who answered "Yes" but indicated wrong examples. }\end{array}$ \\
\hline
\end{tabular}

\section{Result}

\subsection{Perception of Invasive Alien Plants}

All the information and data based on the perception of IAS that is their knowledge, understanding and concern, the way that informed and communicated about the IAS and the method and practices that used by all target groups included in this assessment were present in the following table form.

\subsection{Knowledge, Understanding and Concern}

Table 4. Do you know what is an invasive plant (or invasive alien plant)?

\begin{tabular}{|c|c|c|c|c|c|c|c|c|}
\hline \multirow{2}{*}{ Target group } & \multirow{2}{*}{$\begin{array}{l}\text { Yes } \\
\mathrm{Nb} \\
\end{array}$} & \multicolumn{3}{|c|}{ No } & \multicolumn{2}{|c|}{ No answer } & \multicolumn{2}{|c|}{ Total } \\
\hline & & $\%$ & $\mathbf{N b}$ & $\%$ & $\mathbf{N b}$ & $\%$ & $\mathbf{N b}$ & $\%$ \\
\hline Local farmers & 351 & 73.12 & 103 & 21.46 & 26 & 5.42 & 480 & 100 \\
\hline Zonal, Regional and woreda agricultural experts & 36 & 100 & 0 & 0 & 0 & 0 & 36 & 100 \\
\hline Zonal, Regional and Woreda environment and forest experts & 36 & 100 & 0 & 0 & 0 & 0 & 36 & 100 \\
\hline
\end{tabular}

Table 5. If yes, what do you know?*

\begin{tabular}{|c|c|c|c|c|c|c|c|c|c|c|c|c|}
\hline \multirow{2}{*}{ Target group } & \multicolumn{2}{|c|}{ Its origin } & \multicolumn{2}{|c|}{ Way of introduced } & \multicolumn{2}{|c|}{ Naturalization } & \multicolumn{2}{|c|}{ Expansion } & \multicolumn{2}{|c|}{ Impact on crop biodiversity } & \multicolumn{2}{|c|}{ No answer } \\
\hline & $\mathbf{N b}$ & $\%$ & Nb & $\%$ & $\mathbf{N b}$ & $\%$ & $\mathbf{N b}$ & $\%$ & $\mathbf{N b}$ & $\%$ & $\mathbf{N b}$ & $\%$ \\
\hline Local farmers & 67 & 19.14 & 147 & 41.88 & 101 & 28.77 & 319 & 90.88 & 333 & 94.87 & 5 & 1.42 \\
\hline $\begin{array}{l}\text { Zonal, Regional and woreda } \\
\text { agricultural experts }\end{array}$ & 24 & 66.67 & 29 & 80.56 & 31 & 86.11 & 36 & 100 & 36 & 100 & 0 & 0 \\
\hline $\begin{array}{l}\text { Zonal, Regional and Woreda } \\
\text { environment and forest experts }\end{array}$ & 19 & 52.77 & 25 & 69.44 & 33 & 91.67 & 32 & 88.89 & 36 & 100 & 0 & 0 \\
\hline
\end{tabular}

Note: $-*$ indicated that $\mathrm{n}=351$ for local farmers' $=36$ both zonal, regional and woreda agricultural, environment and forest experts.

Table 6. Do you know examples of invasive plants?

\begin{tabular}{|c|c|c|c|c|c|c|c|c|}
\hline \multirow{2}{*}{ Target group } & \multirow{2}{*}{$\begin{array}{l}\text { Yes } \\
\mathrm{Nb}\end{array}$} & \multicolumn{3}{|c|}{ No } & \multicolumn{2}{|c|}{ No answer } & \multicolumn{2}{|c|}{ Total } \\
\hline & & $\%$ & $\mathbf{N b}$ & $\%$ & $\mathbf{N b}$ & $\%$ & $\mathbf{N b}$ & $\%$ \\
\hline Local farmers & 302 & 62.92 & 133 & 27.70 & 45 & 9.38 & 480 & 100 \\
\hline Zonal, Regional and woreda agricultural experts & 36 & 100 & 0 & 0 & 0 & 0 & 36 & 100 \\
\hline Zonal, Regional and Woreda environment and forest experts & 36 & 100 & 0 & 0 & 0 & 0 & 36 & 100 \\
\hline
\end{tabular}

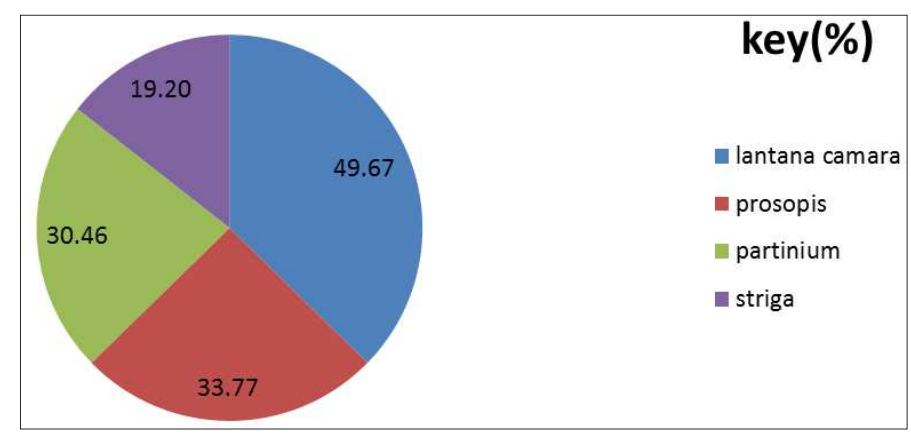

Figure 1. Major invasive plants cited by most of the respondent (top 4 species mostly cited). 
Table 7. At are the impacts of invasive plants?*

\begin{tabular}{|c|c|c|c|c|c|c|c|c|c|c|}
\hline \multirow{2}{*}{ Target group* } & \multicolumn{2}{|c|}{ Ecological } & \multicolumn{2}{|c|}{ Economic } & \multicolumn{2}{|c|}{ Human and animal health } & \multicolumn{2}{|c|}{ On Biodiversity } & \multicolumn{2}{|c|}{ No answer } \\
\hline & $\mathbf{N b}$ & $\%$ & $\mathbf{N b}$ & $\%$ & $\mathbf{N b}$ & $\%$ & $\mathbf{N b}$ & $\%$ & $\mathbf{N b}$ & $\%$ \\
\hline Local farmers & 119 & 33.90 & 192 & 54.70 & 97 & 27.64 & 114 & 32.48 & 4 & 1.14 \\
\hline Zonal, Regional and woreda agricultural experts & 31 & 86.11 & 35 & 97.22 & 36 & 100 & 25 & 69.44 & 0 & 0 \\
\hline Zonal, Regional and Woreda environment and forest experts & 36 & 100 & 29 & 80.56 & 27 & 75 & 32 & 88.89 & 0 & 0 \\
\hline
\end{tabular}

Note: *: Among the respondents who answered yes to the question "do you know what is an invasive plant: $\mathrm{n}=351$ for local farmers $\mathrm{n}=36$ for both zonal, regional and woreda agricultural, environmental and forest experts.

Table 8. Do you think it is an important issue?

\begin{tabular}{|c|c|c|c|c|c|c|c|c|c|c|}
\hline \multirow{2}{*}{ Target group } & \multirow{2}{*}{$\begin{array}{l}\text { Yes } \\
\mathbf{N b}\end{array}$} & \multicolumn{3}{|c|}{ No } & \multicolumn{2}{|c|}{ I don'tknow } & \multicolumn{2}{|c|}{ No answer } & \multicolumn{2}{|c|}{ Total } \\
\hline & & $\%$ & $\mathbf{N b}$ & $\%$ & $\mathbf{N b}$ & $\%$ & $\mathbf{N b}$ & $\%$ & $\mathbf{N b}$ & $\%$ \\
\hline Local farmers & 299 & 62.30 & 43 & 8.95 & 73 & 15.20 & 65 & 13.54 & 480 & 100 \\
\hline Zonal, Regional and woreda agricultural experts & 36 & 100 & 0 & 0 & 0 & 0 & 0 & 0 & 36 & 100 \\
\hline Zonal, Regional and Woreda environment and forest experts & 36 & 100 & 0 & 0 & 0 & 0 & 0 & 0 & 36 & 100 \\
\hline
\end{tabular}

Table 9. Do you feel concerned by the issue?

\begin{tabular}{|c|c|c|c|c|c|c|c|c|c|c|}
\hline \multirow{2}{*}{ Target group } & \multirow{2}{*}{$\begin{array}{l}\text { Yes } \\
\text { Nb }\end{array}$} & \multicolumn{3}{|c|}{ No } & \multicolumn{2}{|c|}{ I don't know } & \multicolumn{2}{|c|}{ No answer } & \multicolumn{2}{|c|}{ Total } \\
\hline & & $\%$ & Nb & $\%$ & Nb & $\%$ & $\mathbf{N b}$ & $\%$ & $\mathbf{N b}$ & $\%$ \\
\hline Local farmers & 363 & 75.63 & 12 & 2.50 & 41 & 8.54 & 64 & 13.33 & 480 & 100 \\
\hline Zonal, Regional and woreda agricultural experts & 36 & 100 & 0 & 0 & 0 & 0 & 0 & 0 & 36 & 100 \\
\hline Zonal, Regional and Woreda environment and forest experts & 36 & 100 & 0 & 0 & 0 & 0 & 0 & 0 & 36 & 100 \\
\hline
\end{tabular}

\subsection{Information and Communication}

Table 10. Do you feel enough and already informed about invasive plants?

\begin{tabular}{|c|c|c|c|c|c|c|c|c|c|c|}
\hline \multirow{2}{*}{ Target group } & \multicolumn{2}{|l|}{ Yes } & \multicolumn{2}{|l|}{ No } & \multicolumn{2}{|c|}{ I don'tknow } & \multicolumn{2}{|c|}{ No answer } & \multicolumn{2}{|c|}{ Total } \\
\hline & $\mathbf{N b}$ & $\%$ & $\mathbf{N b}$ & $\%$ & $\mathbf{N b}$ & $\%$ & $\mathbf{N b}$ & $\%$ & $\mathbf{N b}$ & $\%$ \\
\hline Local farmers & 189 & 39.38 & 167 & 34.80 & 83 & 17.30 & 41 & 8.52 & 480 & 100 \\
\hline Zonal, Regional and woreda agricultural experts & 31 & 86.11 & 4 & 11.11 & 1 & 2.78 & 0 & 0 & 36 & 100 \\
\hline Zonal, Regional and Woreda environment and forest experts & 26 & 72.22 & 7 & 19.44 & 2 & 5.56 & 1 & 2.78 & 36 & 100 \\
\hline
\end{tabular}

Table 11. If yes, do you remember what was the communication channel used?

\begin{tabular}{|c|c|c|c|c|c|c|}
\hline \multirow{2}{*}{ Communication channel } & \multicolumn{2}{|c|}{ Local farmers } & \multicolumn{2}{|c|}{$\begin{array}{l}\text { Zonal, Regional and woreda } \\
\text { agricultural experts }\end{array}$} & \multicolumn{2}{|c|}{$\begin{array}{l}\text { Zonal, Regional and Woreda environment and forest } \\
\text { experts }\end{array}$} \\
\hline & $\mathrm{Nb}$ & $\%$ & $\mathbf{N b}$ & $\%$ & Nb & $\%$ \\
\hline Conference & 68 & 14.17 & 27 & 75 & 21 & 58.33 \\
\hline Internet & 9 & 1.88 & 8 & 22.22 & 13 & 36.11 \\
\hline Article in press & 27 & 5.63 & 11 & 30.56 & 7 & 19.44 \\
\hline Radio or TV reportage & 79 & 16.46 & 3 & 8.33 & 2 & 5.56 \\
\hline Folders, brochures & 0 & 0 & 4 & 11.11 & 10 & 27.78 \\
\hline Article in agricultural magazine & 0 & 0 & 15 & 41.67 & 19 & 52.78 \\
\hline Other & 402 & 83.75 & 29 & 80.56 & 23 & 63.89 \\
\hline I don't remember & 3 & 0.63 & 0 & 0 & 0 & 0 \\
\hline
\end{tabular}

Other communication channels used: through organizations (federation, association, etc.); through discussion with colleagues, through direct consultations (by phone, letter, Email); through training and/or qualification; through personal experience (observation in the field, personal interest) or personal contacts.

\subsection{Control Practices of IAS}

Table 12. Do you have any control practice?

\begin{tabular}{|c|c|c|c|c|c|c|c|c|c|c|}
\hline \multirow{2}{*}{ Target group } & \multicolumn{2}{|l|}{ Yes } & \multicolumn{2}{|l|}{ No } & \multicolumn{2}{|c|}{ I don'tknow } & \multicolumn{2}{|c|}{ No answer } & \multicolumn{2}{|c|}{ Total } \\
\hline & $\mathbf{N b}$ & $\%$ & $\mathbf{N b}$ & $\%$ & $\mathbf{N b}$ & $\%$ & $\mathbf{N b}$ & $\%$ & $\mathbf{N b}$ & $\%$ \\
\hline Local farmers & 415 & 86.46 & 48 & 10 & 12 & 2.50 & 5 & 1.04 & 480 & 100 \\
\hline Zonal, Regional and woreda agricultural experts & 34 & 94.44 & 2 & 5.56 & 0 & 0 & 0 & 0 & 36 & 100 \\
\hline Zonal, Regional and Woreda environment and forest experts & 35 & 97.22 & 1 & 2.78 & 0 & 0 & 0 & 0 & 36 & 100 \\
\hline
\end{tabular}


Table 13. If yes, what are those?

\begin{tabular}{lllllll}
\hline \multirow{2}{*}{ Control method } & \multicolumn{2}{l}{ Local farmers } & \multicolumn{2}{l}{ Zonal, Regional and woreda agricultural experts } & \multicolumn{2}{l}{ Zonal, Regional and Woreda environment and forest experts } \\
\cline { 2 - 7 } & $\mathbf{N b}$ & $\mathbf{\%}$ & $\mathbf{N b}$ & $\mathbf{\%}$ & $\mathbf{N b}$ & $\mathbf{2}$ \\
\hline Cutting & 383 & 79.80 & 16 & 44.44 & 22 & 61.11 \\
Poling & 174 & 36.25 & 17 & 47.22 & 19 & 52.78 \\
Firing & 63 & 13.13 & 13 & 36.11 & 11 & 30.56 \\
Chemical & 0 & 0 & 0 & 0 & 0 & 0 \\
Biological & 0 & 0 & 0 & 0 & 0 & 0 \\
Use and avoid it & 149 & 31.04 & 19 & 52.78 & 25 & 69.44 \\
Preventing & 56 & 11.67 & 23 & 63.89 & 24 & 66.67 \\
\hline
\end{tabular}

Table 14. Do you have any support based on the control method?

\begin{tabular}{|c|c|c|c|c|c|c|c|c|}
\hline \multirow{2}{*}{ Target group } & \multicolumn{2}{|l|}{ Yes } & \multicolumn{2}{|l|}{ No } & \multicolumn{2}{|c|}{ No answer } & \multicolumn{2}{|c|}{ Total } \\
\hline & $\mathbf{N b}$ & $\%$ & $\mathbf{N b}$ & $\%$ & $\mathbf{N b}$ & $\%$ & $\mathbf{N b}$ & $\%$ \\
\hline Local farmers & 277 & 57.71 & 172 & 35.83 & 31 & 6.46 & 480 & 100 \\
\hline Zonal, Regional and woreda agricultural experts & 19 & & 17 & & 0 & 0 & 36 & 100 \\
\hline Zonal, Regional and Woreda environment and forest experts & 27 & & 9 & & 0 & 0 & 36 & 100 \\
\hline
\end{tabular}

Note:- these they said yes from the above table indicates that both governmental organization like Ethiopian Biodiversity institute, environment and forest authority as well as agricultural sectors and different non-governmental organization like care in Ethiopia, Menschen for Menschen are there most supporting organization regarding to control IAS on their locality.

Table 15. What will be you recommendation based on controlling IAS?

\begin{tabular}{|c|c|c|c|c|c|c|}
\hline \multirow{2}{*}{$\begin{array}{l}\text { Recommendation that were raised by } \\
\text { the target group }\end{array}$} & \multicolumn{2}{|c|}{ Local farmers } & \multicolumn{2}{|c|}{$\begin{array}{l}\text { Zonal, Regional and woreda } \\
\text { agricultural experts }\end{array}$} & \multicolumn{2}{|c|}{$\begin{array}{l}\text { Zonal, Regional and Woreda environment } \\
\text { and forest experts }\end{array}$} \\
\hline & $\mathbf{N b}$ & $\%$ & $\mathbf{N b}$ & $\%$ & $\mathbf{N b}$ & $\%$ \\
\hline Get high attentions by government & 324 & 67.50 & 30 & 83.33 & 17 & 47.22 \\
\hline Need all community participation & 205 & 42.71 & 27 & 75 & 32 & 88.89 \\
\hline Including in education curriculum & 12 & 2.5 & 16 & 44.44 & 12 & 33.33 \\
\hline $\begin{array}{l}\text { Give high attention that both import and } \\
\text { export materials }\end{array}$ & 49 & 10.21 & 13 & 36.11 & 23 & 63.89 \\
\hline $\begin{array}{l}\text { Get more awareness about its general } \\
\text { characteristic }\end{array}$ & 467 & 97.23 & 31 & 86.11 & 33 & 91.67 \\
\hline Linkage of institution & 109 & 22.71 & 22 & 61.11 & 21 & 58.33 \\
\hline
\end{tabular}

\section{Discussion}

\subsection{Knowledge, Understanding and Concern}

Generally from the above tables (4-9) we are understand that the target groups perception and understanding based on the type and even identification of IAS from indigenous pants, the knowledge what they know about IAS, major list of IAS indicated by the target group, understanding about the impact of IAS on different aspects, how much the issue was very hot issue on their area and even we can understand that their thinking how much feel on it and make it their concerning issue as well. The level of knowledge was evaluated by analyzing answers to questions related to the definition, impacts and examples of invasive plants (see material and methods). When we see the level of knowledge of the target group from the first table (table 4) of result part, especially the local farmers, most of them around 351 (73.12\%) has the idea about IAS and from this we can understand that how much the issue becomes concerned and very critically serious issue on our agricultural biodiversity.
The impact on crop biodiversity and rate of expansion are the two most characteristics that are known by most of the local farmers (table 5). And this indicates that the economic, ecological and loss of biodiversity are the most serious impact respectively due to introduction of IAS that understand by the local farmers (table 7). And both the zonal, regional and woreda agricultural, environment and forest experts are totally $72(100 \%)$ of them they have the knowledge about IAs and also they are the concerned body on this regarding to aware the local farmers about its side effect both on agricultural biodiversity, ecological, forest, environment as well as the side effect of them on both human and animal health. And this is in agreement with the study that conducted in France, agricultural and environmental impact is also the most frequently cited by local farmers and nursery producers, public departments and garden contractors [6]. The most common IAS that were listed by both the local farmers and the experts were lantana camara (49.67\%), prosopis juliflora (33.77\%), parthenium hystrophorus $(30.46 \%)$ and striga spices $(19.20 \%)$ were the most dominated and highly affected on both agricultural biodiversity, ecology and also on human and animal health 
(Fig.1). In general we can understand from the data that were collected both from the local farmers as well as from experts the issue of IAS are very critical at all level and most of the local farmers $299(62.30 \%)$ were indicated that this issue currently hot spot in all aspect (table 8). And most of them $363(75.63 \%)$ of the local farmers and the whole experts 72 $(100 \%)$ of them indicated that the issue needs the concern of the whole society, even not part of eastern area of the country. and it need the whole community cooperation in order to reduce and if it is possible eradicate from the area that were highly dominated and all its impacts (table 9).

\subsection{Information and Communication}

When I tried to asking to the target group how much they were informed on IAS, most of the target groups that was local farmers 189 (39.38\%), agricultural experts 31 (86.11\%) and environment and forest experts 26 (72.225) of them were have enough and already informed about the general features of IAS (table 10). But even most of the target groups have enough information about IAS still most of them 167 $(43.80 \%)$ of local farmers, 4 (11.11\%) agricultural experts and $7(19.44 \%)$ of environment and forest experts were they have not any information about IAS (table 10). From this we can understand that Still awareness creation with regard to IAS general features with in the community is the basic and highly needed as well as we should consider it the first serious point in order to prevent the impact of IAS. When we see the communication channels most frequently used in order to get information about IAS are (1) conferences or information sessions; (2) internet; (3) folders and brochures; (4) articles in agricultural magazines; (5) articles in press, (6) radio and TV reportage and (7) others (table 11). This indicates that respondents are generally informed through several communication channels. The communication channels used differ among the target groups. When we see the local farmers the most common communication channel that they used to get information about IAS were 402 $(83.75 \%)$ of them through personal experience that is from filed observation, $79(16.46 \%)$ of them were from radio and TV reportage and $68(14.17 \%)$ of them were through different conference (table11). And when we see both agricultural and environment and forest experts they were used different communication channels in order to get information about IAS as compared to local farmers and from this conferences and personal experience like training were the most common (table 11). from this we can understand than both local farmers and also the experts were mostly depends on social communication rather than internet and different article papers. so in order to addressed the information to the society again awareness creation through different training and conference should be taken as the leading point according to this assessment data.

\subsection{Control Practices of IAS}

When we see from table 12 most of the target groups 415 $(86.46 \%)$ of the local farmers, $34(94.44 \%)$ of agricultural expert and almost all 35 (97.22\%) of environment and forest experts were not only information about IAS rather they can developed and apply their own control mechanism since it is very critical and highly affected on both their economical, ecological as well as both human and livestock health. From the control methods that applied by the local farmer cutting $383(79.80 \%)$, poling $174(36.25 \% 0$ and use and avoid it 149 $(31.04 \%)$ were the three most control methods respectively (table13). And when we see the experts recommendation on the control method of IAS preventing, use and avoid it, cutting and poling were the most and highly recommended control mechanism of IAS respectively as we see from table 13 .

Based on the prevention and control system of IAS there were other collaborative and supportive both governmental and non-governmental organization. From the assessment data that were collected from this target group Ethiopian Biodiversity Institute, both regional, zonal and woreda agricultural, environment and forest authority were the supportive governmental organization and Care Ethiopian and Menschen for Menschen were the two most supporting nongovernmental organization that work on awareness creation and control of IAs in Eastern part of Ethiopia (table 14).

Finally, from the target group the following basic recommendation were forwarded with regarding to IAS prevention, Control, avoid its impact on both economical, ecological, environmental and in general biodiversity lose aspect. There are Get high attentions by government, Need all community participation, Including in education curriculum, Give high attention that both import and export materials, Get more awareness about its general characteristic and Linkage of institution in order to prevent and manage the effect of IAS (table 15). From the above recommendation forwarded by the target group awareness creation with in the community was indicated as the most and the first chose in order to control and achieve total change on the impact of IAS followed by give high attention by the country government as we see from table 15 .

\section{Conclusion and Recommendation}

This assessment was performed from three target groups a total of 552 respondents and the assessment was focused on the general knowledge (definition based on their own term, example, general features, issues and their concern) about IAS of the target group, their impact in all aspect especially on agricultural perspectives, the way to know how much they sense its impact and how to get the information about IAS and the method that they try to control in their locality as well as their internal idea what they need to do further on it. From assessment data II try to conclude is that all the target group weather the experts as well as the local farmers they have knowledge about IAS and currently IAS become the first and the most Serious problem that affected on their agricultural biodiversity, range lands, ecology and even their health. And they have their own control mechanism that mostly tries to control the distribution and impact of IAS and there is also some supporting organization with them based 
on Control method on it. Finally they also recommend further support and cooperation with regard to its fast and aggressive expansion of IAS and from these data I also recommend that in order to achieve effective and fruitful effect on the eradication and control of IAS both governmental and non-governmental organization even at individual level do more on awareness creation and try insert strong internal idea the community how much they are danger in all our life if we cannot control and eradicate it.

\section{References}

[1] Andersen MC, Adams H, Hope B, Powell M (2004). Risk assessment for invasive species. Risk Analysis 24: 787-793.

[2] Convention on Biological Diversity (2002) Report of the Sixth Meeting of the Conference of the Parties to the Convention on Biological Diversity, UNEP/CBD/COP/6/20, 27 May 2002, 348 pp.

[3] Geesing D, Felker P, Bingham RL (2000) Influence of mesquite (Prosopis glandulosa) on soil nitrogen and carbon development: Implications for global carbon sequestration. Journal of Arid Environment 46: 157-180, http://dx.doi.org/10. 1006/jare.2000.0661.

[4] Goulson D, Derwent LC (2004). Synergistic Interactions Between an Exotic Honeybee and an Exotic Weed: Pollination of Lantana camara in Australia. Weed Res. 44: 195-202.

[5] Grice AC (2006). The impacts of invasive plant species on the biodiversity of Australian. Rangelands 28: 27.

[6] Guerin M., Provendier D. (2012). Gestion preventive des plantes exotiques envahissantes: rapport d'enquete aupres des professionnels de l'horticulture. Plante et cite. France. 38 pg.

[7] Halford M., Heemers L., Mathys C., Vanderhoeven S., Mahy G. (2011). Socio-economic survey on invasive plants and ornamental horticulture in Belgium. Final report. University of Liege Gembloux Agro Bio-Tech (Belgium). 29 pg.

[8] Haysom, K. A. and Murphy, S. T. (2003). The status of invasiveness of forest tree species outside their natural habitat: a global review and discussion paper. Forest Healthand Biosecurity Working Paper FBS/3E. Forestry Department. FAO, Rome (unpublished).
[9] Hesselink F. J., Wendy Goldstein W., Van Kempen P. P., Garnett T., Dela J. (2007). Communication, Education and Public Awareness (CEPA): a toolkit for National Focal Points and NBSAP coordinators. Secretariat of the Convention on Biological Diversity and IUCN. Montreal (Canada). 310 pg.

[10] Mack RN, Simberloff D, Lonsdale, WM, Evans H, Clout M, Bazzaz FA (2000). Biotic Invasions: Causes, Epidemiology, Global Consequences, and Control. Ecol. Appl. 10: 689-710.

[11] Malik RN, Husain SZ (2007). Broussonetiapapyrifera (L.): An Environmental Constraint on the Himalayan Foothills Vegetation. Pak. J. Bot. 39: 1045-1053.

[12] McGinley. (2007). Effects of the biological invasion of algaroba: P. juliflora (Sw.) DC. On composition and structure of the shrub-tree stratum of the caatinga in Monteiro Municipality, Paraiba State, Brazil. Biodiversity, Ecology and Environmental health 20 (4): 887-898. ISSN 0102-3306.

[13] Pimentel D, Lach L, Zuniga R, Morrison D (2000). Environmental and Economic Costof Non- Indigenous Species in the United State. Bioscience 50: 53-65.

[14] Richardson DM, Binggeli P, Schroth G (2004). Invasive agroforestry trees: problems and solutions. In: Schroth, G., de Fonseca GAB, Harvey CA, Gascon C, Vasconcelos H, Izac AMN (eds), Agroforestry and Biodiversity Conservation in Tropical Landscapes, pp. 371-396. Island Press, Washington, D. C.

[15] Richardson DM, Pysek P, Rejmánek M, Barbour MG, Panetta FD, West CJ (2000) Naturalization and invasion of alien plants: Concepts and definitions. Diversity and Distribution 6: 93-107, http://dx.doi.org/10.1046/j.1472-4642.2000.00083.x.

[16] Sanders RW (2006) Taxonomy of Lantana sect. Lantana (Verbenaceae): I. correct application of Lantana camara and associated names. Sida Contributions to Botany 22: 381-421.

[17] Stohlgren TJ, Otsuki CA, Villa M, Belnap J (2001). Patterns of Plant Invasions: A Case Example in Native Species Hotspots and Rare Habitats. Biol. Invasions 3: 37-50.

[18] Vanderhoeven S., Piqueray J., Halford M., Nulens G., Vincke J., Mahy G. (2011). Perception and understanding of invasive alien species issues by nature conservation and horticulture professionals in Belgium. Environmental Management 47: 425-442. 